\title{
The presentation of mental disturbance in modern Scottish literature
}

\author{
Allan Beveridge
}

Correspondence to Dr Allan Beveridge, Consultant Psychiatrist, Queen Margaret Hospital, Whitefield Road, Dunfermline, FIFE KY12 OSU, UK; allanbeveridge@nhs.net

Accepted 20 November 2016

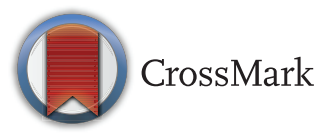

To cite: Beveridge $\mathrm{A}$. Med Humanit

2017:43:81-85

\section{ABSTRACT}

The subject of madness features throughout world literature, but the literature of modern Scotland appears to be especially preoccupied with it. This paper gives a brief overview of the ways in which madness is represented in modern Scottish literature and the different artistic functions it performs. It will consider the subject on a thematic basis. First, there are accounts by writers who have experienced mental turmoil themselves. Second, there is the theme of the 'Narrative of personal crisis' which depicts in fictional form an individual's journey through madness. Third, there is the theme of the 'Gothic or divided selves'. The fourth theme is that of the 'Female voice' and the last is that of 'Outsiders and holy fools', whose existence is to unsettle the beliefs of a wider society.

Although the subject of madness features in the literature of most countries, the literature of modern Scotland appears to be especially preoccupied with it. This paper gives a brief overview of the ways in which madness is represented in modern Scottish literature and the different artistic functions it performs. It will consider the subject on a thematic basis. First, there are accounts by writers who have experienced mental turmoil themselves. Second, there is the theme of the 'Narrative of personal crisis' which depicts in fictional form an individual's journey through madness. Third, there is the theme of the 'Gothic or divided selves'. A key text in this is The Private Memoirs and Confessions of a Justified Sinner by James Hogg (1824), which provides a double narrative contrasting the supernatural with the 'rational'. The fourth theme is that of the 'Female voice' and includes Elspeth Barker's $O$ Caledonia, AL Kennedy's Paradise and much of the work of Muriel Spark. The last theme is that of 'Outsiders and holy fools', whose off-kilter utterances and behaviour serve as a subversive commentary on wider society.

In The Scottish Novel since the Seventies, Gavin Wallace $^{1}$ noted that modern Scottish writers were especially interested in the subject of mental derangement. He observed:

As Tom Leonard's poem puts it, there is 'nuthnlik disperr' to keep you going, and there is no despair like Scottish despair better calculated to throttle the most innocent of affections: hence James Kelman's grimly logical and literal refinement of the condition into disaffection. Disaffection not only keeps the Scottish novel going-it seems positively in love with it. In English novels, the deranged, the desperate, the neurotic and the variously addicted might provide the odd deviant diversion to emphasise the reassuring normality of everything else. In Scottish novels, they are narrators and protagonists, rarely, if ever, fully in control of their existences, and morbidly aware of the fact. The literary revival of the 1970 s succeeded in the compellingly imaginative depiction of Scotland as the one country best designed to drive anyone with the faintest glimmer of an imagination quietly insane...

\section{FROM THE INSIDE}

Several Scottish writers have experienced mental and emotional problems, and have written about them directly, rather than through fiction. In the introduction to her book, On Bullfighting (1999), AL Kennedy ${ }^{2}$ recounts a period of despair in her life when she attempted suicide. She describes reaching a point when she was unable to write and felt worthless. She planned to jump out the window of her tenement flat. As she was getting ready to jump, she heard a man down below singing (very badly) 'Mairi's Wedding'. She decided she could not possibly kill herself to the accompaniment of a song she hated and which she regarded as Celtic kitsch. Kennedy extracts humour out of a situation that is seemingly bleak and hopeless. The reader follows her narrative, fearing the worst, only to find an unexpected comic element introduced. This juxtaposition of dark subject matter and humour seems to be a particularly Scottish trait. Perhaps, it is a way of dealing with disturbing experiences.

In The One (2003), Paul Reed ${ }^{3}$ describes his experience of schizophrenia and being a patient in the Royal Edinburgh Hospital. He captures the often terrifying nature of the condition: being bombarded with voices and feeling that one's innermost thoughts are broadcast to the outside world. Reed conveys the relentless and exhausting experience of being psychotic.

In his autobiographical A Lie About My Father (2006), the Fife poet and novelist, John Burnside, ${ }^{4}$ describes his drug-induced psychosis and admissions to Fulbourn psychiatric hospital in Cambridge. Before becoming mentally ill, Burnside was aware of the romantic notions of madness as an exalted state. Rimbaud had advised that the poet must undergo a derangement of the senses to become a true poet, while Blake had claimed that a life of excess led to higher knowledge. In a passage which mocks these ideas, Burnside writes:

The road of excess leads to the palace of wisdom. It's a lie of course; but then, Blake was always a bit of a fraud... remarkably free of the Rimbaldian excesses that the church of latter-day visionaries to which I belonged had come to believe were de rigueur. We were asphalt visionaries, of course: DIY amateurs poring over the sacred texts in the mercuric light of our own befuddled minds... 
For many of Burnside's fellow visionaries, the road to excess led to disaster. And yet Burnside found his experience of madness of value. He was fascinated with 'the theatre of possibilities' that his mind produced: the tiny elephants, the circus acrobats and the 'Water Girl' who changed shape and followed him with sinister intent. However, he left hospital tired with the road to excess and with the preoccupation with the self. He found that the actual experience of mental derangement did not quite accord with the pronouncements of the poets.

The Edinburgh poet, Jo McFarlane, ${ }^{5}$ has written of her experience of severe mental illness and psychiatric treatment in Skydiving for Beginners (2014). Born into abject poverty, subjected to parental neglect and sexual abuse as a child, plagued by recurrent bouts of severe mental illness in adult life, Jo McFarlane relates this deeply disturbing, yet affecting, story with a lack of self-pity and a startling degree of candour. In the midst of an Arts degree at Edinburgh University, she suffered her first serious mental breakdown and was admitted to the Royal Edinburgh Hospital. For years to come, she had repeated admissions, often detained under the Mental Health Act, as a result of near-successful suicide attempts. McFarlane does not hide how disturbed she was, how difficult she could be with psychiatric staff or the serious nature of her suicide attempts.

\section{THE NARRATIVE OF PERSONAL CRISIS}

As well as personal accounts of mental illness, there are, of course, countless fictional depictions. In A Social History of Madness: Stories of the Insane, Roy Porter ${ }^{6}$ identified three stages in the narrative of personal crisis, or what we might call the narrative of secular salvation. The writer adopts the framework of the spiritual autobiography: there is the fall from grace, the subsequent journey through the dark night of the soul and the sudden illumination which leads to salvation. Thus, the secular writer records his first mental faltering, his struggle with madness, his recovery through pills or therapy, and his attainment of a new understanding of self and others. This model can be applied to the work of Iain Crichton Smith and Alasdair Gray.

Iain Crichton Smith ${ }^{7}$ based his novel, In the Middle of the Wood (1987), on his own experience of madness brought on by a creative block. ${ }^{8}$ He had taken early retirement from teaching and felt guilty that he was unable to write. He became mentally ill and was eventually admitted to a psychiatric hospital. In the novel, the hero, Ralph Simmons, also has writer's block. Like Crichton Smith, he develops a paranoid psychosis and spends time in hospital. Crichton Smith's novel charts the progress of an aloof, arrogant character who endures the torments of imagined persecutions, receives sudden illumination after weeks in hospital and recovers his sanity. He has paid the price for his contempt for others and rejoins the world of 'ordinary people'. Thus, the novel follows the stages of secular salvation from crisis to redemption.

Iain Crichton Smith ${ }^{9}$ was deeply aware of the tradition linking madness with creativity. Indeed, prior to his breakdown, he had declared that the Scottish poet needed to go mad to break free from 'the extraordinary sanity at the heart of Scotland'. This belief informed Crichton Smith's own encounter with madness: surely a real artist should journey to the extremes of insanity? However, Crichton Smith found the actual experience of insanity quite different to his perceptions. He did not become more creative and attain poetic truths; instead, he found it a profoundly bleak experience, devoid of artistic activity.

Author and artist Alasdair Gray ${ }^{10}$ has freely admitted that he has experienced emotional and mental difficulties at certain periods in his life. As an adolescent, he suffered from asthma and acknowledged there was a strong psychological component to it. Following a severe asthmatic attack, he was referred to a psychiatrist, an encounter which he portrayed in Lanark (1981). As a young man, he was depressed, and took three overdoses in the wake of failed relationships. He was interested in psychiatric literature and read Freud, Jung and Wilhelm Reich. He was personally acquainted with RD Laing, read The Divided Self and discussed psychology with him.

Gray is very familiar with the Scottish literary depiction of mental disturbance, a tradition which includes James Hogg's Confessions of a Justified Sinner, Stevenson's Dr Jekyll and $\mathrm{Mr}$ Hyde and George Douglas Brown's The House with Green Shutters. He has also been influenced by European works such as Dostoyevsky's Notes from the Underworld, Ibsen's Peer Gynt and Celine's Journey to the End of the Night, which all deal with mentally troubled characters.

In Gray's ${ }^{11}$ magnum opus, Lanark, the hero, Duncan Thaw, is a gifted young artist, beset by psychosomatic illness, who wishes to produce a work of genius. He is brought down by poverty, an uncomprehending world and his own arrogance. He is unable to find love, and sexual relations are unsuccessful because women find his skin condition repellent. His great art project, a mural in a church, is to be torn down before it is completed. Thaw becomes psychotic, and his long night of the soul ends in suicide, though he is seemingly reborn as the character Lanark in the fantasy section of the book.

Gray's $^{12}$ next full-length novel after Lanark (1982) was Janine (1984), in which the main character also endures a long night of the soul, but, unlike Thaw, he attains redemption. Although Gray stated that he wanted to write about a character that was different from himself and his fictional alter ego, the artistic Duncan Thaw, he ended up creating a character, Jock McLeish, who had many similarities. As he conceded: "by making him wholly opposite I produced a negative selfportrait". ${ }^{13}$ Indeed, Gray drew on his own youthful experiences at the Edinburgh Festival to sketch the early life of McLeish, and it is possible that he also drew on his own experiences of heavy drinking to portray the older, by now, alcoholic McLeish. The novel traces McLeish's breakdown and eventual alcoholfuelled suicide attempt.

McLeish uses alcohol and pornography to avoid facing up to his problems. The novel takes the form of a monologue in which McLeish muses over his life and his current situation. The action takes place in a hotel room where McLeish is drinking heavily. After a dark night of the soul, during which he overdoses, he survives and achieves some kind of personal enlightenment. He will resign from his job and start anew.

\section{THE GOTHIC OR DIVIDED SELVES}

Originating in 1764 with Horace Walpole's 'The Castle of Oranto', the term, 'Gothic' evoked disquieting interiors of castles, crypts and convents. These were replaced by disquieting interiors of madness and self-division. This theme of selfdivision can be traced through James Hogg's ${ }^{14}$ The Private Memoirs and Confessions of a Justified Sinner and Robert Louis Stevenson's The Strange Case of Dr Jekyll and Mr Hyde to modern novels such as Alasdair Gray's Poor Things and Iain Banks' The Wasp Factory. RD Laing's existential psychiatric classic, The Divided Self, can also be seen as belonging to this tradition. Of course, novels from outside Scotland also deal with such themes, notably Bram Stoker's Dracula.

Hogg's Confessions of a Justified Sinner has been very influential. It was one of the first novels to deal with the double and 
divided selves, ${ }^{15}$ and, some 150 years before Postmodernism, it provided more than one narrative of events.

The novel tells of a young man, Robert Wringhim, who is brought up in the Calvinist religion to believe that he is one of the elect and comes to reason that all his actions are good. God has chosen him to rid the world of sinners. The novel provides two accounts: one by a fictitious 'Editor', representing the Voice of Enlightenment Reason, who considers Wringhim is insane; and a second by Wringhim, himself, which provides a supernatural reading. Hogg does not privilege either version and, indeed, there are discrepancies in the 'Editor's' account. The reader is left to decide for themselves which is the most believable.

Wringhim claims he is possessed by the devil. He writes:

I felt a sort of invisible power that drew me towards him, something like the force of enchantment which I could not resist... What was my astonishment, on perceiving that he was the same being as myself! The clothes were the same to the smallest item. The form was the same; the apparent age; the colour of the hair; the eyes; and... the features too were the very same.

\section{And again:}

I was a being incomprehensible to myself. Either I had a second self, who transacted business in my likeness, or else my body was at times possessed by a spirit over which it had no control, and of whose actions my own soul was wholly unconscious.

Although published in 1824, Hogg's novel has had more impact in our times following its rediscovery by Andre Gide in 1947. A whole host of modern Scottish novels bear its influence.

James Robertson's ${ }^{16}$ first novel, The Fanatic (2000), clearly pays homage to Hogg's novel. It concerns a character called Andrew Carlin who is a tour guide in contemporary Edinburgh. $\mathrm{He}$ is a divided character who is split between his modern-day role and the character of a 17th century 'Justified Sinner'. Andrew is a student misfit, who hears voices and talks to himself in the mirror. Robertson ${ }^{17}$ returned to the theme of selfdivision in The Testament of Gideon Mack (2006). This concerns a minister who is undergoing a crisis which can be interpreted either as evidence that he is mad or that he is possessed by the devil. Like Hogg, Robertson does not privilege either interpretation.

The Canongate Strangler (1990) by Angus McAllister ${ }^{18}$ tells the story of Edward Middleton, an Edinburgh lawyer, who seems to have a double who carries out murders. The reader has to decide: Is Middleton a psychopath telling lies? Is he psychotic? Is he possessed? In a statement which clearly echoes Hogg's Robert Wringhim, the narrator writes: "My body has been taken over by an evil puppet-master and I myself am committing the atrocity, a paralysed witness of my own actions". At the end of the novel, there is a psychiatric report which states that Middleton suffers from schizophrenia. The device of having what purports to be a psychiatric report occurs in several other novels. The diagnosis of 'schizophrenia' is also a recurring theme in these novels: a diagnosis which had entered contemporary culture at the time many of them were being written, though now the reference to autistic disorders is more common.

'The Curious Incident of the Dog in the Night Time by Mark Haddon was the first of several novels in which the central character is autistic. In popular culture, television programmes such as Sherlock, The Big Bang Theory and The Simpsons also feature autistic characters.
In The Bad Sister (1978) by Emma Tennant, ${ }^{19}$ the central character is Jane, a young woman who belongs to a magical, political commune of women. She seems to have a double who commits murders. Has she been brainwashed? Is she a victim of evil or magic forces? Is she mad? Again, the novel incorporates a psychiatric report, and again, the diagnosis is 'schizophrenia'.

In an early Inspector Rebus novel, Wolfman (1992), by Ian Rankin, ${ }^{20}$ the killer is a well-to-do male barrister who has an evil, female, second personality who carries out the crimes. Once again, there is a psychiatric report, and the diagnosis is 'schizophrenia'. Rankin appears to be portraying schizophrenia in accord with the popular misconception that is a condition manifest by a 'split personality'. Likewise, Irvine Welsh ${ }^{21}$ in his novel, Filth (1998), portrays schizophrenia in the same way. The central character, Detective Sergeant Bruce Robertson, experiences himself as two people-a man and a woman. He hears voices, commits murder, then suicide. We are told that he suffered from schizophrenia, as did his father.

Other Scottish novels deal with divided selves. In The Wasp Factory (1984) by Iain Banks, ${ }^{22}$ the major division concerns gender. The troubled central narrator, Frank, is divided between the stereotypes of male and female behaviour. In The Other McCoy (1990) by Brian McCabe, ${ }^{23}$ the eponymous hero, Pat McCoy, seems to have a doppelganger-the other McCoy. Or has he just been drinking too much? Alasdair $\mathrm{Gray}^{24}$ draws heavily on James Hogg's Confessions of a Justified Sinner, as well as Mary Shelley's Frankenstein, in his Poor Things (1992). Set in the 19th century, the novel provides two conflicting narratives of the same events-a fantastic one and a prosaic one-as well as an overview by the 'Editor'. In the fantastic version, a young, pregnant woman, Bella Baxter, drowns herself in the Clyde, but is reanimated and saved by having the brain of her baby transplanted into her skull. Her subsequent child-like behaviour suggests mental instability, and she is seen by the leading European alienists of the day. In the prosaic version, Bella, or Victoria McCandless as she prefers to be known, denies that these events took place and claims her husband made them up.

\section{THE FEMALE VOICE}

Female authors do not just confine themselves to writing feminist critiques of the construction of madness and the power of psychiatry, though some such as Janice Galloway and Maggie O' Farrell are particularly interested in this area. Instead, female writers, like their male counterparts, adopt a variety of approaches to madness, although filtered through a feminine sensibility.

In her influential book, The Female Malady, Elaine Showalter ${ }^{25}$ examined attitudes to female madness in British culture. She found that 'madness' could be used as a term to invalidate women who do not conform to the female stereotype. Psychiatric discourse, which until recently has been overwhelmingly masculinist, has shaped how women are viewed and treated. Madness could be seen as an understandable reaction to patriarchal society. However, Showalter felt there are dangers in romanticising mental illness in females: if it is a form of rebellion, it is a failed one.

A novel which explicitly confronts psychiatric issues is Maggie O'Farrell's ${ }^{26}$ The Vanishing Act of Esme Lennox (2006). Set in Edwardian Edinburgh, it tells the story of Esme, a young woman who repeatedly embarrasses her bourgeois family in polite society. She is outspoken and unconventional. As a result, she is locked up in an asylum for most of her adult life. In the acknowledgements, the author explicitly mentions the book, 
Sanity, Madness and the Family by two Scottish psychiatrists, RD Laing and Aaron Esterson. ${ }^{27}$ They had suggested that schizophrenia was a label applied to people, particularly women, who did not conform to values of their family.

In her first novel, The Panopticon (2012), Jenni Fagan ${ }^{28}$ offers a more complex account of how institutions treat females. The novel tells of Anais Hendrick, a troubled 15-year-old girl, who spends much of her time in and out of institutions for disturbed and delinquent adolescents. She feels she is part of what she calls 'the Experiment', which, on one level, is understandable. She is indeed under surveillance by the state and subject to the orders of police and social workers. But there is also the suggestion that she is mentally disturbed and has a paranoid view of her situation. The novel is therefore ambiguous and more subtle than O' Farrell's straightforward equation of institutions with social repression.

Another novel which examines the female encounter with psychiatry and institutions is The Trick is Keep Breathing (1989), by Janice Galloway, ${ }^{29}$ who has, herself, experienced mental illness. This is the story of Joy Stone, a schoolteacher, who has been having an affair with a married man who drowns. The novel charts her subsequent breakdown and her dealings with the psychiatric professionals, who are portrayed as unhelpful and uncaring. Inadvertently, the novel captures the often solipsistic and self-centred nature of mental distress.

The novels of Muriel Spark often feature mentally disturbed characters $^{30}$; these include, for example, The Hothouse by the East River; Not to Disturb; Aiding and Abetting and The Finishing School. Spark ${ }^{31}$ wrote her first novel, The Comforters (1957), to understand her own mental breakdown, and also to learn how to write a novel. The heroine, Caroline Rose, suffers delusions and appears to herself as a character in the novel we are reading. A typewriter taps in her head, speaking the narrative of her life, predicting it. Torn between spiritual and the medical explanations of her experiences, she goes mad.

Spark is examining the conventions of fiction, whereby the author is the invisible puppet master, and the characters, but puppets, entirely controlled by the author. The characters are 'predestined' to follow the author's plot. Spark is also examining belief in the divine. If there is a God, are human beings set to follow his plans or is there room for free will? Spark asks questions about the nature of madness: can it best be understood in spiritual or psychological terms? Characteristically, she does not give a definitive answer.

The Hothouse by the East River (1973) was based on Spark's ${ }^{32}$ experience of living in New York in the early 1960s. It takes a satirical and critical look at psychoanalysis and the self-obsessed citizens of the city. For Spark, psychoanalysis intrudes into normal human suffering and gives people permission to be self-indulgent. It militates against stoicism and acceptance of the tragic dimensions of life.

Agnes Owens frequently depicts disturbed individuals, but she does not romanticise their plight. She adopts an unsentimental view of her characters who are often unpleasant or selfdeluding. Gender or low social class does not confer victimhood or hero status. For the Love of Willie ${ }^{33}(1998)$ is the story of Peggy who relates her story from a mental hospital, where she has been admitted because of infanticide. She is writing a book, but says: "Who would want to read about an old trout like me, in a nuthouse too, and not even mad enough to be interesting?" In A Working Mother ${ }^{34}$ (1994), Betty tells her story of infidelity, marital break-up, alcohol abuse and eventual detention in a psychiatric hospital. She is an unreliable narrator who does not see her own part in her downfall.
In O Caledonia (1991) by Elspeth Barker, ${ }^{35}$ the central character is Janet, a misfit girl, who romanticises her mad aunt Lila. Barker suggests that Janet is misguided in her estimation of her aunt. Barker draws on stock Gothic imagery to paint an unflattering picture of Aunt Lila. She is otherworldly a lover of cats and a social recluse. She is rumoured to be a sorceress who has poisoned her husband. Barker writes: 'Sometimes at dusk she slipped out among the trees and howled like a wolf. Alone in her room she uttered strange cries and clawed her face into raw furrows'.

Another novel which debunks romantic notions of mental disturbance is Paradise (2004) by AL Kennedy. ${ }^{36}$ This novel is concerned with severe alcoholism and delirium tremens. It is told by Hannah Luckcraft, who provides a bleak and unsparing account of the degradations of drink. It is, however, told with humour and lack of self-pity.

\section{OUTSIDERS AND HOLY FOOLS}

Outsiders and holy fools appear throughout world literature, most notably in that of Shakespeare, Dostoyevsky and Camus. However, they appear with great regularity in Scottish literature, from Galt's Sir Andrew Wylie through McDonald's Sir Gibbie to Robin Jenkins' Fergus Lamont. Douglas Gifford ${ }^{37}$ has written: 'The Scottish writer from an authoritarian and religious pedigree finds release through parody and grotesque self-abasement, and a transformation takes place in which the concept of grace is altered to allow a more human face'.

As well as writing In the Middle of the Wood, Iain Crichton Smith also created a comic character, Murdo, ${ }^{38}$ which provided him with another way of dealing with his breakdown and feelings of being an outsider. Murdo's bizarre actions and surreal talk mark him out as a misfit, indeed a madman in the Scottish village in which he lives. He writes letters to Dante. He informs the papers that Calvin is alive and well and living in the Highlands. He inquires at the library for War and Peace, the one written by Hugh MacLeod. He wants to write, but faces creative inertia.

In her novel, Symposium (1990), Muriel Spark ${ }^{39}$ creates a character called Magnus, who is the mad uncle and guru of the Murchie family. Here, madness is presented as a state which is superior to dull conformity. Spark writes of Uncle Magnus, 'Although he was decidedly mad, he was the least boring of all [the family]'. She also comments: 'Magnus was the only imaginative factor that had ever occurred in the Murchie's family, but unfortunately he was mad'.

Despite the fact he is insane, Magnus is regarded as the guru of the family. The author notes: 'families do not normally consult the mad people even if they have lucid periods, the families do not go to them for advice. The Murchies were different'. One relative observes that in the Middle Ages, the insane were considered to be 'divinely illuminated'. Spark is portraying madness as a condition which may be associated with wisdom and the attainment of spiritual insights. But, as ever with Spark, the picture is ambiguous. Is Magnus a force for good or evil? Is Magnus a guide or the family's worst enemy?

In Sleeping with Jane Austen (2000) by David Aitken, ${ }^{40}$ Daniel Adamson is detained in Camperdown Hospital for the Criminally Insane for a series of sex crimes. He is the unreliable narrator of the novel, and he proves to be narcissistic, superior, pretentious, self-deluding, disorganised and comic. His motto is: 'Woe to the man with a little originality'. The Quarry (2013) by Iain Banks ${ }^{41}$ is told through the eyes of Kit, an autistic youth. He observes: "It helps that I am very clever, if challenged in other ways. Challenged in this context means that I am 
weird, strange, odd, socially disabled, forever looking at things from an unusual angle". In The Man who Walks (2002) by Alan Warner ${ }^{42}$ the mysterious eponymous hero is either a madman who wanders around the country with grandiose beliefs that he has written film scripts and music, or he is some kind of savant, touched by the hand of God.

\section{CONCLUSION}

This paper has presented a brief overview of how madness is portrayed in modern Scottish literature, and, of course, it cannot claim to be comprehensive. Nevertheless, certain themes have emerged which go some way to explaining why mental disturbance is such a recurring subject in modern Scottish literature. First, there is the long Scottish literary tradition of interest in the supernatural, the Gothic and the religious, all of which posit other worlds, other realities. Madness too posits other realities and thus lends itself to exploring these realms. Scottish writers from Hogg onwards have been reluctant to pronounce dogmatically on whether madness is best understood in material or spiritual terms and have left it to the reader to judge whether characters are mad or in the midst of a religious crisis. Robert Wringhim in Hogg's Confessions of a Justified Sinner is the classic example of this.

Many writers have drawn on their own experiences of mental turmoil, such as AL Kennedy, Iain Crichton Smith, Alasdair Gray, John Burnside and Muriel Spark. Mental disturbance has been used as a means of examining personal identity, subjects in which Scots are particularly interested. Crichton Smith's Murdo, Gray's Duncan Thaw, Galloway's Joy Stone and Fagan's Anais Hendrick are examples of this. It has also been used to analyse the national character, as in Gray's Jock McLeish whose obedience to authority and failure to realise his potential are portrayed as reflecting traits of the Scottish character.

Then there is the Scottish sense of humour, which is often dark. There is a tendency to treat disturbing subjects in a comic manner, which is often a way of coping with them. Of course, Irish writers such as Samuel Beckett also adopt this strategy. AL Kennedy's account of her own suicide attempt manages to make a very grim event humorous, and also conveys how desperate she felt. The novels of Gray, Banks and Crichton Smith provide other examples of the humorous treatment of disturbed mental states.

We also have to consider the influence of psychiatric discourse on Scottish literature. Certainly, many writes acknowledge the influence of RD Laing. His The Divided Self can be seen in the tradition of Hogg and Stevenson, which deals with self-division. In turn, Laing has influenced Tom Leonard, Alasdair Gray and Janice Galloway. As we have seen, Maggie O' Farrell's The Vanishing Act of Esme Lennox makes direct reference to Laing.

As should be apparent, several factors have contributed to the preoccupation of many modern Scottish writers with mental disturbance. We will leave the last word to Tom Leonard ${ }^{43}$ who was quoted at the start of this paper:

nuthnlik desperr

keepsyi gawn

a hawf boatl ur behtr stull

a fuhl wan

Competing interests None declared.

Provenance and peer review Not commissioned; externally peer reviewed.

\section{REFERENCES}

1 Wallace G. Voices in Empty Houses. The Novel of Damaged Identity. In: Wallace G, Stevenson R, eds. The Scottish Novel since the Seventies. Edinburgh: Edinburgh University Press, 1993:217-31.

2 Kennedy AL. On Bullfighting. London: Yellow Jersey Press, 1999.

3 Reed P. The One. Edinburgh: Mercat Press, 2003.

4 Burnside J. A Lie About My Father. London: Jonathan Cape, 2006.

5 MacFarlane J. Skydiving for Beginners. A Journey of Recovery and Hope. Edinburgh: Scottish Independent Advocacy Alliance, 2014.

6 Porter R. A Social History of Madness. Stories of the Insane. London: Weidenfield \& Nicolson, 1987.

7 Crichton Smith I. In the Middle of the Wood. London: Gollancz, 1987.

8 Beveridge A. Metaphors of Madness. lain Crichton Smith's Journey through the Inferno Hist Psych. 1996;7:375-95.

9 Gow C. Mirror and Marble. The Poetry of lain Crichton Smith. Edinburgh: Saltire, 1992.

10 Glass R. Alasdair Gray. A Secretary's Biography. London: Bloomsbury, 2008.

11 Gray A. Lanark. Edinburgh: Canongate, 1981.

12 Gray A. 1982, Janine. London: Jonathan Cape, 1984.

13 Acker K. Alasdair Gray Interviewed by Kathy Acker: 1986. In: Moores P, eds. Alasdair Gray. Critical Appreciations and a Bibliography. London \& Boston Spa: The British Library, 2002: 45-58.

14 Hogg J. The Private Memoirs and Confessions of a Justified Sinner. London: Penguin Books, 1983 (originally published in 1824).

15 Beveridge A. James Hogg and Abnormal Psychology. Some Background Notes. Studies in Hogg and his World 1991;2:91-4.

16 Robertson J. The fanatic. London: Fourth Estate, 2000

17 Robertson J. The testament of Gideon Mack. London: Hamish Hamilton, 2006.

18 MacAllister A. The canongate strangler. Glasgow: Dog and Bone, 1990.

19 Tennant E. The bad sister. London: Victor Gollancz, 1978.

20 Rankin I. Wolfman. London: Century, 1992.

21 Welsh I. Filth. London: Jonathan Cape, 1998.

22 Banks I. The wasp factory. London: MacMillan, 1984.

23 McCabe B. The other McCoy. Edinburgh: Mainstream, 1990.

24 Gray A. Poor things. London: Bloomsbury, 1992.

25 Showalter E. The Female Malady. Women, Madness and English Culture, 18301980. New York: Pantheon Books, 1985.

26 O' Farrell M. The Vanishing Act of Esme Lennox. London: Headline Review, 2006

27 Laing RD, Esterson A. Sanity, Madness and the Family. London: Penguin, 1964.

28 Fagan J. Panopticon. London: William Hienemann, 2012.

29 Galloway J. The Trick is to Keep Breathing. Edinburgh: Polygon, 1989.

30 Beveridge A. 'We are all a little mad in one or other particular'. The presentation of madness in the novels of Muriel Spark. Hist Psych 2016;27 (106):153-171.

31 Spark M. The comforters. New York: New Directions, 1957.

32 Spark M. The hothouse on the East River. London: Penguin, 1973.

33 Owens A. For the love of Willie. London: Bloomsbury, 1998.

34 Owens A. A working mother. London: Bloomsbury, 1994.

35 Barker E. O Caledonia. Norwich: Galley Beggar Press, 2014 (originally published in 1991).

36 Kennedy AL. Paradise. London: Jonathan Cape, 2004

37 Gifford D. Bleeding from all that is Best. The Fiction of lain Crichton Smith In: Wallace G, Stevenson R. eds. The Scottish Novel since the Seventies. Edinburgh: Edinburgh University Press, 1993: 25-40.

38 Crichton Smith I. Murdo and Other Stories. London: Gollancz, 1981.

39 Spark M. Symposium. London: Constable, 1990.

40 Aitken D. Sleeping with Jane Austen. Harpenden: No Exit Press, 2000.

41 Banks I. The Quarry. London: Little Brown, 2013.

42 Warner A. The Man Who Walks. London: Jonathan Cape, 2002.

43 Leonard T. Intimate Voices. Selected works, 1965-1983. Newcastle uponTyne: Galloping Dog Press, 1984. 